\title{
Improving geodynamic monitoring practice in underground gas storage areas
}

\author{
Stepan Shevchuk ${ }^{1 *}$, Svetlana Kvyatkovskaya ${ }^{1}$ and Roman Shevchuk ${ }^{2}$ \\ ${ }^{1}$ LLC Gazprom UGS, 196105, Moskovsky prospekt, 139, bld. 1., Saint-Petersburg, Russia \\ ${ }^{2}$ LLC NVK “Gorgeomekh”, Varshavskoye shosse, 129, bld. 2., Moscow, Russia
}

\begin{abstract}
This article consideres issues of geodynamic monitoring during the construction and operation of underground gas storage facilities. Existing methods of geodynamic monitoring used in Russia and other countries are reviewed. A brief overview of the accidents occurred during the construction and operation of underground gas storage facilities is presented. A suggestion is put forward to expand the scope of geodynamic monitoring carried out, taking into account current thinking on the nature of geodynamic hazard involved in operation of engineer constructions located underground

Keywords: underground gas storage facility, geodynamics, monitoring, rock salt, underground surveying, integrity.
\end{abstract}

\section{Introduction}

Underground gas storages (UGS) are currently in operation in many countries of the world [1]. Sustainable development of the fuel and energy complex of Russia depends directly on the consistency of natural gas supplies. Currently there are 23 operating underground gas storage facilities in the Russian Federation.

The operation of UGS is a sophisticated technological process where standard operating conditions depend on many factors. The key feature of UGS is seasonal fluctuation of demand. During the summer period, gas is pumped in; as soon as the storage volume is filled up to the set scribe mark, the injection is stopped, and after a certain neutral period gas withdrawal is carried out during winter months.

Underground gas storages are a source of anthropogenic impacts. Subject to the Federal Law of the Russian Federation No. 116 of July 21, 1997, UGSs are classified as hazardous production facilities.

The requirements for environmental integrity during the construction and operation of UGSs are strictly regulated by legislative and statutory documents of the Russian Federation. Geodynamic monitoring of operating UGS is obligatory, and this is regulated by standard process documentation. An overview of these papers is presented in [2]. This article deals with the current state and issues of geodynamic monitoring management at UGSs.

\footnotetext{
*Corresponding author: Shevchuk.Stepan@yandex.ru
} 


\section{UGS classification}

Underground storage facilities are part of the gas supply system in many countries. Their function is to adjust irregularity in gas consumption, and they also serve as peak-shaving and just-in-time gas stocks.

The development of the gas industry in our country demands that large underground gas storage facilities are built to ensure the reliability of the domestic and export gas supplies.

According to the International Gas Union data, the most significant gas storage facilities are located in three regions, as can be seen in Table 1. Gas storage capacity is growing annually in all countries. For example, the capacity in Asia has increased by $15 \%$ in recent years due to new UGSs built in China. The volume of stored gas in Russia is also expected to increase in the coming years due to commissioning of new underground gas storage facilities.

Table 1. Global underground gas storage capacity

\begin{tabular}{|c|c|c|}
\hline \multicolumn{2}{|c|}{ Global underground gas storage capacity } \\
\hline Region & $\begin{array}{c}\text { Working capacity, } \\
\text { BIn } \mathbf{~ m}^{\mathbf{3}}\end{array}$ & $\begin{array}{c}\text { Share of Global UGS } \\
\text { capacity }\end{array}$ \\
\hline North America & 138,1 & $38 \%$ \\
\hline $\begin{array}{c}\text { CIS (Former Soviet } \\
\text { Republics) }\end{array}$ & 113,6 & $32 \%$ \\
\hline Europe & 96,7 & $28 \%$ \\
\hline Asia & 7,0 & $2 \%$ \\
\hline Middle-East & 1,4 & $0 \%$ \\
\hline Latin America & 0,1 & $0 \%$ \\
\hline Total & $\mathbf{3 5 7 , 0}$ & $\mathbf{1 0 0} \%$ \\
\hline
\end{tabular}

Two types of UGS are of the greatest interest in the world practice - those in porous geological structures and those in rock salt formations.

The current development of underground gas storage facilities is characterized by an increased interest in the construction of underground gas storage facilities in salt caverns. Reservoirs in rock salt have a significantly higher daily gas withdrawal rate and at the same time it is believed that salt caverns are the safest type of underground gas storage facilities, due to specific mechanical properties of rock salt [1].

Technologically, each UGS is a complex artificial void made underground that can have an impact on the surrounding rock and hydrosphere, and in cases of possible gas leakage on the atmosphere.

\section{Setting up and executing geodynamic monitoring at UGS}

Surveying and geodetic observations shall be set up at the geodynamic site as well as full, systematic and quality control over geomechanical condition of the enclosing rock and the earth's surface shall be ensured to mitigate the negative impact of works on structures and facilities at and around UGS location in accordance with mineral resources conservation regulations of the Russian Federation.

According to paragraph 263 of the Guidelines No. 07-603-03, geological reasoning for the creation of the mine surveying system shall be drafted. This paper shall include the assessment of displacements and deformations of the earth surface taking into account the 
natural stress-strain state of the rock and its changes in the process of construction and operation, their maximum values shall be determined.

One of the main purposes of geodynamic monitoring is to observe the condition of surface infrastructure. Therefore, it is mandatory to assess the permissible and limiting exposure on surface infrastructure.

A project shall also be developed for surveying and geodetic observations (setting up a geodynamic test site) in the area where the UGS is to be located, which includes the structure of the geodynamic test site and the procedures for carrying out the work. Depending on the geological conditions of the area where the UGS is located and the features of natural or induced geodynamic processes, the measurement time interval can vary, and this provision shall be included into the project documentation.

Observations at the geodynamic test site envisage creation of an observation station consisting of reference benchmarks and deformation telltales for grade II accuracy leveling. Satellite observations with high tech GNSS equipment are widely used to determine the projected displacements. Occasionally, GNSS measurements do not reveal horizontal displacements of the earth's surface with the required accuracy. Therefore, classical methods of observation of projected displacements (trilateration) should be in place using a high-precision electronic tacheometer to conduct high-precision monitoring at a geodynamic test site.

It is known from the fundamentals of geomechanics that during volumetric deformation, horizontal displacements in the central part of the target site shall be zero, whereas vertical displacements reach their maximum values.

Let us consider the results of duplicate mine surveying and geodetic observations at a UGS geodynamic test site in Figure 1. For the convenience of data reviewing the graphic material of just a single profile is presented.

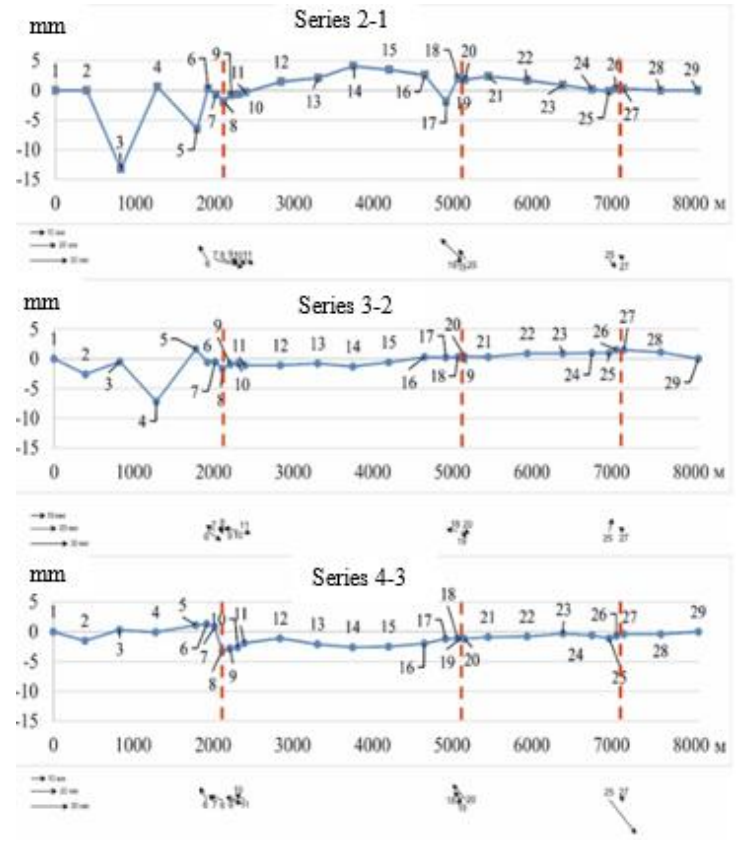

Fig. 1. Correlation between vertical and horizontal displacements of the earth's surface along profile $1-1$.

Profile 1-29 is located across the UGS strike and crosses 3 fault zones. Figure 1 displays chaotic mode of horizontal displacements. Maximum amplitudes of the vertical 
displacements turned out to be an order of magnitude smaller than those of the horizontal ones. This example shows that due to low resolving power of satellite measurements they are not capable to detect horizontal displacements of the surface.

Gravimetric observations are an integral part of instrumental monitoring. They are aimed at identifying dynamic anomalies in time, changes in gravity forces on the earth's surface which are caused by changes in density characteristics at depth.

To ensure geoecological integrity in the construction and operation of underground gas storage facilities abroad, complex monitoring is applied, namely: observations of the surface subsidence, micro-seismic monitoring, hydroacoustic surveys, pressure control and temperature control.

\section{Most common accidents in UGS operation}

UGS operating history dates back more than a century. The first UGS was built in 1915 in Canada.

Accidents of various nature are known in UGS operating history, examples of which are presented in Table 2 .

Table 2. Some of the most common accidents in UGS operation

\begin{tabular}{|c|c|c|c|}
\hline № & UGS facility, country & Accident details & $\begin{array}{l}\text { UGS } \\
\text { type }\end{array}$ \\
\hline 1 & $\begin{array}{l}\text { Playa del Rey, LA, } \\
\text { California, USA }\end{array}$ & $\begin{array}{c}\text { Gas migrated from Playa del Rey structure into a } \\
\text { neighbouring structure from earliest days. Cause partly } \\
\text { due to faults }\end{array}$ & $\begin{array}{c}\text { Depleted } \\
\text { deposit }\end{array}$ \\
\hline 2 & $\begin{array}{l}\text { Montebello, LA, } \\
\text { California, USA }\end{array}$ & $\begin{array}{l}\text { Gas migrated from injection area and lost over } \\
\text { extended period }\end{array}$ & $\begin{array}{c}\text { Depleted } \\
\text { deposit }\end{array}$ \\
\hline 3 & Kiel, Germany & Salt creep leading to lost capacity & Salt bed \\
\hline 4 & $\begin{array}{l}\text { East Whittier, } \\
\text { California, USA }\end{array}$ & $\begin{array}{l}\text { Gas migrated from original injection site and produced } \\
\text { by another company }\end{array}$ & $\begin{array}{c}\text { Depleted } \\
\text { deposit }\end{array}$ \\
\hline 5 & Tersanne, France & Salt creep leading to lost capacity & Salt bed \\
\hline 6 & $\begin{array}{l}\text { El Segundo, California, } \\
\text { USA }\end{array}$ & Gas migrated from reservoir to surface & $\begin{array}{c}\text { Depleted } \\
\text { deposit }\end{array}$ \\
\hline 7 & $\begin{array}{c}\text { Eminence, Mississippi, } \\
\text { USA }\end{array}$ & $\begin{array}{l}\text { Salt creep caused by operating at too low pressure, } \\
\text { capacity lost }\end{array}$ & Salt bed \\
\hline 8 & $\begin{array}{l}\text { Castaic Hills and Honor } \\
\text { Rancho, California, } \\
\text { USA }\end{array}$ & $\begin{array}{c}\text { Gas migrated from Castaic reservoir, via faults, to } \\
\text { adjacent shallower reservoirs and subsequently to } \\
\text { surface }\end{array}$ & $\begin{array}{c}\text { Depleted } \\
\text { deposit }\end{array}$ \\
\hline 9 & Epps, Louisiana, USA & $\begin{array}{l}\text { Gas migrated away from injection footprint and } \\
\text { produced elsewhere }\end{array}$ & $\begin{array}{c}\text { Depleted } \\
\text { deposit }\end{array}$ \\
\hline 10 & $\begin{array}{l}\text { Conway, McPherson } \\
\text { County, Kansas, USA }\end{array}$ & $\begin{array}{l}\text { Gas found in wells and local groundwater possibly } \\
\text { caused by wet rockhead }\end{array}$ & Salt bed \\
\hline 11 & Mineola, E. Texas, USA & $\begin{array}{c}\text { Cavern operations led to connection between adjacent } \\
\text { caverns, pressure build up and casing leak }\end{array}$ & Salt bed \\
\hline 12 & $\begin{array}{l}\text { Clovelly, Louisiana, } \\
\text { USA }\end{array}$ & $\begin{array}{l}\text { Cavern leaching in the salt overhang. Insufficient } \\
\text { thickness of salt to act as a barrier }\end{array}$ & Salt bed \\
\hline 13 & $\begin{array}{l}\text { Napoleanville, } \\
\text { Louisiana, USA }\end{array}$ & $\begin{array}{l}\text { Shale layers of salt dome side encountered in some } \\
\text { caverns leading to insufficient buffer salt. }\end{array}$ & Salt bed \\
\hline 14 & JK-A cavern, China & The collapse of the cavern roof & Salt bed \\
\hline 15 & $\begin{array}{c}\text { Osipovichskoye UGS, } \\
\text { Belarus } \\
\end{array}$ & Gas flow to overlying strata & $\begin{array}{c}\text { Depleted } \\
\text { deposit }\end{array}$ \\
\hline
\end{tabular}


The UGS accident/incident analysis identified 59 cases, including 27 cases in salt caverns and 32 depleted field cases. There were 8 fatal accidents, all of them recorded at the UGS facilities in the salt beds, the USA. Causes, nature and consequences of the incidents varied. The classification of accidents broken down by geological conditions as shown in Figure 2 may be of principal interest to our country (Russia).

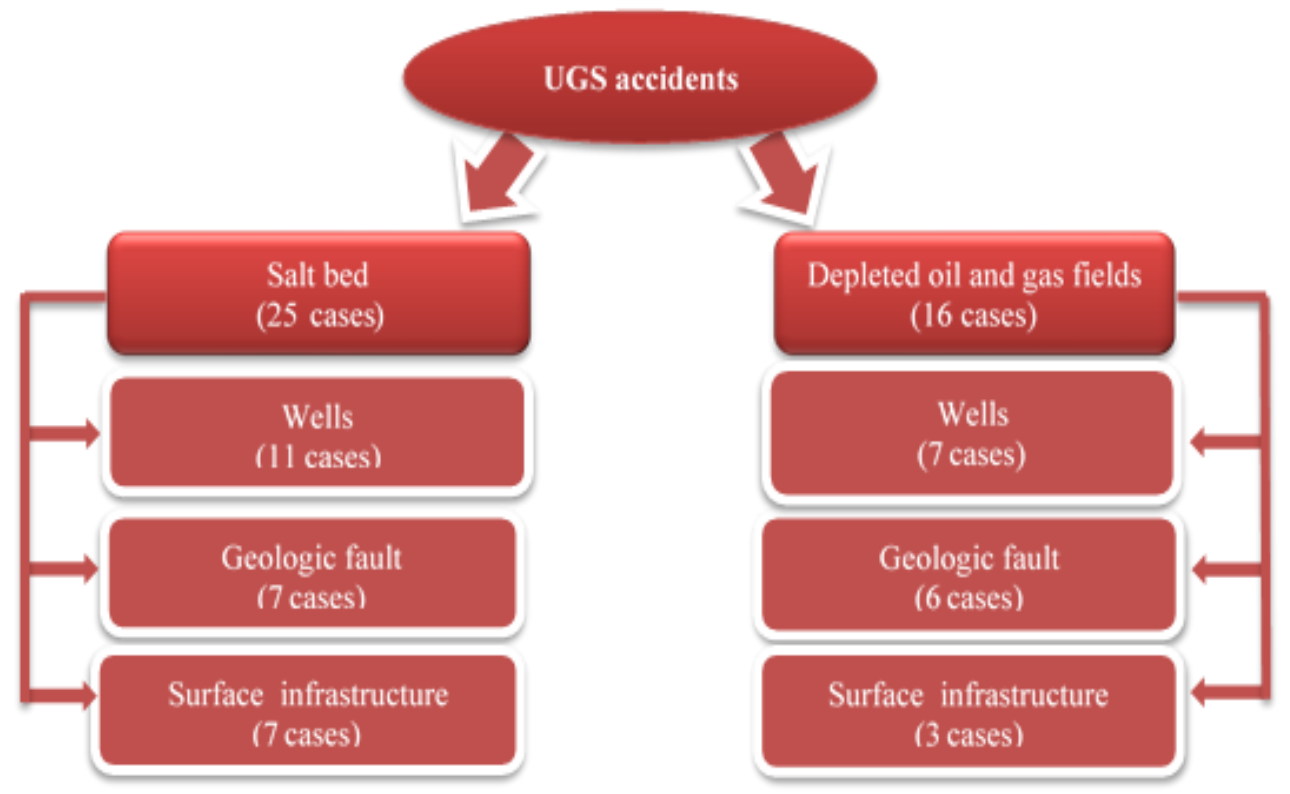

Fig. 2. Accident classification

Geological disturbance implies integrity violation of the geological structure in which the underground repository is built. The key reason for that is the insufficient geological knowledge of the field wherein the UGS is located.

Thus, accidents recorded in the salt rock were caused by destruction of the cavern located on the salt dome edge. There is also the risk of destruction of closely spaced caverns. Another reason may be the change in the cavity volume.

The greatest number of accidents that occurred in depleted fields were recorded in California. This state represents a developed area in terms of oil and gas industry, and it is also susceptible to high seismicity. The main causes of accidents - integrity violation of the geological strata resulting from geodynamic process activation.

Other UGS malfunctions were caused by the failure of the infrastructure, i.e. wells and surface engineering facilities, and the most common cause of these incidents was the human mistake factor

\section{Potential ways of developing integrated monitoring at UGSs}

An overview of accidents at UGSs provided above shows that despite monitoring practices were in place, unforeseen situations may arise at operating UGSs that would cause accidents with loss of gas content and environmental impact. This means that there is a need to improve the monitoring technique at such hazardous facilities. Apparently, it demands to acknowledge achievements of modern science and technology in this area and take full advantage of them.

Intensive resource utilization in the 20th century has led to qualitative changes in the forms of geodynamic hazard manifestations in mining areas. Research on geomechanics 
and geodynamic zoning established the relationship between global and local geodynamic processes [3-8]. The establishment of such a relationship is one of the most important results of geomechanical and geodynamic research in the past century [9]. Aggravation of induced seismicity, abnormal deformations of the earth's surface, integrated environmental effect of geodynamic processes [10-19] are observed in mining regions. Taking into account current understanding of the hierarchical-block structure of the rock [3, 20-22 ] the presence of regional and local tectonically stressed and unloaded zones therein, including zones of critical stress [23], achievement in field of monitoring [24- 27] it can be assumed that the inclusion of engineering facilities such as UGSs into this natural system can also lead to their geodynamic interaction and mutual influence. It is important to know that the costs involved in impact analysis of natural and man-made phenomena, as well as systematic monitoring are hugely less than those involved in emergency response and remediation. In this connection, feasibility study is required focused at the expansion of the geodynamic monitoring scope to assess the impact of global and local geodynamic processes in the UGS areas to ensure their safe operation.

\section{Conclusions}

Geodynamic monitoring of an operating UGS includes approproate procedures to monitor local geomechanical processes in the immediate vicinity of the facility.

Despite ongoing efforts to select the most appropriate location sites for UGS facilities and their monitoring, serious incidents with break of airtightness, loss of contents and environmental impact keep occurring.

Considering that present-day science has traced the relationship between local and global geodynamic processes involved in exploitation of mineral resources, feasibility study is required focused at the expanded scope of geodynamic monitoring over UGS operation to achieve all-inclusive and reasonable account of possible manifestations of this relationship.

\section{References}

1. A.K. Smirnov, Underground gas storage in aquifers («Kompanija Sputnik+», Moscow, 2003).

2. S.S. Kvyatkovskaya, S.V.Shevchuk, R.V. Shevchuk, J. Monitoring. Sc. \& technologies, 2(40), 20-23 (2019).

3. I. M. Batugina, I. M. Petukhov Geodynamic zoning of mineral deposits for planning and explotation of mines. (New Delhi: Oxford \& IBH Publishing Co. Pvt. Ltd.,1990).

4. Kundu, B., Vissa N.K., Gahalaut V.K, Res. Lett, 42, 10607-10613 (2015).

5. M. Keiding, T. Arnadottir, S. Jonsson, J. Decriem, A, Iceland J. Volcanol. Geotherm. Res., 194, 139-149 (2010)

6. A.S. Batugin, I.M. Batugina, T. Lan, J. of Liaoning Technical University, 35(6) 561565 (2016). DOI: 10.11956/j.issn.1008-0562.2016.06.

7. Saksin B.G., Rasskazov I.Yu., Shevchenko B.F, J. of Mining Sc, 2,243-252 (2015)

8. C.D. Klose, Earth Sci., 66, 1439-1447 (2012), 10.1007/s12665-011-1355-7

9. Geomechanical fields and processes: Experimental-analytical research into initiation and growth of accidental event in mining-engineering and natural systems / Melnikov N.N. (Chief Editor), Novosibirsk, Russia, 2018;

10. I. Yu. Rasskazov, B. G. Saksin, V. I. Usikov, M. I. Potapchuk, Gornyi Zhurnal, J. Mining, 12, 13-19 (2016). Doi: 10.17580/gzh.2016.12.03.

11. T. Li, M.F. Cai, M. Cai, Int. J. Rock. Mech. Min. Sci. 44, 1149-1171 (2007) 
12. A. Batugin, A. Myaskov, Y. Ignatov, E. Khotchenkov, D. Krasnoshtanov, J. Earth and Environmental Sc., 221(1) (2018) Doi:10.1088/1755-1315/221/1/012089

13. L. Tianwei, Z. Hongwei, H. Jun, et al., J. of Mining \& Safety Enginer., 29(6), 840-845 (2012)

14. I. Yu. Rasskazov, D. S. Migunov, P. A. Anikin, A. V. Gladyr', A. A., Tereshkin, D. O. Zhelnin, J. Mining Sc. 51(3), 614-623 (2015)

15. Y. Yu, D.X. Geng, L.-H. Tong, X.-S. Zhao, X.-H. Diao, L.-H. Huang, Int. J. Geomech. 18(7), Art. No. 06018016 (2018)

16. A. S. Batugin, V. N. Odintsev, K. S. Kolikov, Ev. V. Khotchenkov, Proceeding of the 2018 European Rock Mechanics Symposium (EUROCK-2018, Saint-Petersburg, Russia), 593-598 (2018)

17. A. S. Batugin, V. N. Odintsev, Y Lijiang, Ev. V. Khotchenkov, SGEM, 18(1.3), 319326 (2018)

18. A. S. Batugin, A Kobylkin, V Musina, K Daniil, SGEM, 18(1.3), 1111-1118 (2018). Doi:10.5593/sgem2018/1.3/S03.140

19. A. Batugin, V. Musina, I. Golovko, (IOP Conference Series: Earth and Environmental Science, 95 (2017) 042023. Doi :10.1088/1755-1315/95/4/042023.

20. J. Han, H.W. Zhang, S. Li, (2009). Research on rockburst based on the hierarchy of rock mechanics system. (The, International Symposium on Rockbursts and Seismicity in Mines), 8, 427-434 (2009)

21. Rasskazov I.Yu., Saksin B.G., Petrov V.A., et al. Izvestiya, Phys. of the Solid Earth, 3, 444-452 (2014)

22. Osokina, D.N.. J.of Geodynamics, 10(2-4), 331-344 (1988)

23. A.S. Batugin, E3S Web of Conferences 56, Article ID 02007, (2018) Doi: 10.1051/e3sconf/20185602007

24. Rasskazov I.Yu., Dolgikh G.I., Petrov V.A., et al, J. of Mining Sc, 6, 29-37 (2016).

25. B. Rosado, A. Fernández-Ros, M. Berrocoso, G. Prates, A. Geyer, J. of Volcanology and Geothermal Research, 381, 57-82 (2019)

26. Kh. L. Khamidov, Geodesy and Geodynamics, 8, 34-40 (2017)

27. A. Tachema, A. Nadji, Journal of Atmospheric and Solar-Terrestrial Phys., 183, 1-10 (2019) 